\title{
SOCIAL MEDIA AS A TOOL OF DESTINATION MARKETING ORGANIZATIONS
}

\author{
Jovan Popesku \\ Singidunum University, Serbia
}

\begin{abstract}
:
The development of information and communication technologies, especially Internet, has a strong influence on the changes in the use of marketing tools. The existence and availability of the Internet have fundamentally changed the way how tourists access information, how do they plan and book their travel, and in which way they share the travel experience with others. An important step forward in the development of the Internet has been made by a significant growth in the prevalence of social media platforms that allow Internet users to collaborate, communicate and publish original content. Web 2.0 has marked a shift towards taking responsibility by users on the Internet, which resulted in the increasing importance of customers and the decreasing authority of marketers.

Social media are especially important for tourism, which is information-intensive activity. Tourism consumers need information that can help them in the process of travel planning and decision making related to the selection of tourist destinations as well as of different types of tourism products. Personal recommendations are particularly important in this context, because of the intangibility of tourism products. Social media provide this with the content created by the consumers (consumer-generated content - CGC), and with the comments that can be trusted.

Social media has a special significance for the activities of destination marketing organisations (DMaOs). Destinations marketers can use social media before the travel (to inspire, inform, engage), during the travel (to facilitate at destination) and after the holiday (to remember, share and engage).

Non-acceptance of the use of social media by DMaOs will cause a decrease in their competitive advantage. The risk associated with using social media that is particularly highlighted is the lack of relevant researches. The basic prerequisite for the proper use of social media as destination marketing tool is the adoption of the strategies for their use.

Recognising the importance of the use of social media by tourist destinations, especially by $\mathrm{DMaO}$, this paper analyses the basic characteristics of the social media usage by destination marketing organisations in Serbia at local, regional and national level.
\end{abstract}

\section{Key words:}

Internet,

social media, tourist destinations, destination marketing organisations, Serbia.

\section{INTRODUCTION}

The Internet is the most important innovation since the development of the printing press [1]. The Internet combines many of the features of existing media with new capabilities of interactivity and addressability; thus, it transforms not only the way individuals conduct their business with each other, but also the very essence of what it means to be a human being in society [2]. Since the emergence of the Internet, travel planning (e.g., travel information search and booking) has always been one of the main reasons that people use the Internet [3]. The creation and accessibility of the Internet have fundamentally changed how travellers access information, the way they plan for and book trips, and the way they share their travel experiences [4].

One significant development in the evolution of the Internet is the increasing prevalence of social media platforms that enable Internet users to collaborate, communicate and publish original content such as blogs, videos, wikis, reviews, or photos [5]. Social media has become the modus operandi of the $21^{\text {st }}$ century. Building on the foundation of Web 2.0, social media applications have facilitated unprecedented growth in human interaction in modern times [6].

The use and impact of the Internet on the society and economy can be considered as one of the key factors for the global transformation in the late twentieth and early 
twenty-first century. In this regard, the use of the Internet for marketing purposes and the technology based on it represents one of the most important developments in the performance of the overall marketing activities, and especially promotional ones.

The main benefits that the Internet offers to potential users can be summarised as: permanent availability under reasonable conditions, the global character, providing special value by facilitating comparisons of prices and products, and facilitating the process of decision-making on a purchase based on the assessment of alternative products and offers by service providers.

Internet has an impact on the use of all marketing instruments by providing product improvement, reducing the costs of searching for information on new products and services, and serving as a new channel to access the market / distribution, which led to the significant elimination of mediation that is typical for the tourism business.

Tourism market can be also defined as specific because of the interweaving and mutual interpenetration of information providing and promotional activities, especially tourism propaganda. The value of information is derived from their systematic nature, comprehensiveness, completeness, objectivity and specificity. Tourism represents basically an information-intensive activity, where there is a high risk in information exchange between buyers and sellers.

The effect of these factors causes that tourism is directly impacted by technological changes, which are related to the whole process of transmission of information at all levels. The key technological breakthrough in this field was made by the development of telecommunications and communications technology (ICT) that facilitate the collection, storage, analysis, transmission, and dissemination of information. Their connection has created the opportunities for remote transmission and processing of information which, by definition, have a great "consumption "in tourism.

The main benefit is related primarily to facilitate the process of decision making by a management company or a tourist destination. Information and communication technology was initially used to accelerate the processing and transfer of information within company / destination, and then between company / destination and business partners and, as a logical extension, between company and final users - the consumers. This is particularly important for the service sector and, within that, for tourism as an activity that deals with the creation and sale of intangible experiences related to travel and tourism.

Remote information processing between individual companies / destinations or between companies / destinations and consumers, is conducted continuously, more and more efficiently and with the lower price. In this case also, a competitive advantage in the marketplace is reached by those companies and destinations that use the technological changes in order to formulate marketing strategy and to combine marketing mix instruments that are focused to the demands, desires and needs of consumers. It is, in essence, the creation of an enlarged / added value for the consumer, and the use of technology to fa- cilitate the decision-making of consumers on traveling for tourism. This is done essentially by providing relevant information and improving the quality of services, or the tourist product.

This area is one of the most exposed to turbulent changes, which is in line with the fast development of information technology. That development has caused that we can talk about the increase in directing marketing, especially promotion activities, to so-called "electronic" or "digital" marketing. The basis for this diversion is an increasing use of the Internet for the marketing activities of business and tourism policy carriers. [7] The main impacts of information and communication technologies (ICT) on marketing activities in the tourism and hospitality industry can be summarised as follows [8]:

- The initial benefits of ICT were aimed to companies, increasing the efficiency with which they communicated with customers. The longer-term marketing effects of ICT appear likely to increase power of the customer (ability given to the people to 'shop around' for bargains and choose from a much wider selection of travel opportunities than those offered by the main travel agency and tour operator chains). The choice available to consumers has increased owing to a number of other supplyside factors alongside the Internet (deregulation of air travel and the rise of the low-cost carriers, political changes such as the abolition of visa requirements and adoption of common European currency). The result is that the market is increasingly dominated by a new type of visitor: affluent, independent, confident and curious to discover new places and cultures

- Consumers have become accustomed to using the Internet not only to obtain information but also for the purpose of the booking and final purchase of tourism products,

- Strategic changes in the tourism sector - the possibility for customers to be able to compare online prices of all essential parts of the tourism product, the harmonisation of regulations and standards, the elimination of restrictions in the services sector, consumer protection and the wide application of quality management;

- Much larger selection of tourist destinations that are available to potential guests, often at the expense of existing developed tourist destinations;

- Moving from an economy based on services to the economy based on experiences, which is supported by data on the growing economic importance of products based on the experience (wine roads, culinary delights, adventure and various kinds of activities, arts, cultural events) compared to those based on the service;

- In these new conditions, new opportunities arise also for small businesses in the tourism and hospitality industry, related to the products aimed to the niche markets. This is primarily due to the fact that making a website does not require significant resources and that the potential guests are willing 
to search the Internet in order to find acceptable solutions. In this respect ICT helps small and medium-sized enterprises in their joint presentations and in the cooperation with destination management organisations in the creation of portals and links to better expose their own websites;

- Support of the public sector and associations of local tourism enterprises to SMEs is crucial for their strategic use of the Internet and the creation of a destination management system that should be used as a source of information and a place for booking and the purchase of the partial destination tourism products.

One significant development in the evolution of the Internet is the increasing prevalence of social media platforms that enable Internet users to collaborate, communicate and publish original content such as blogs, videos, wikis, reviews, or photos [9]. Social media has become the modus operandi of the 21st century. Building on the foundation of Web 2.0, social media applications have facilitated unprecedented growth in human interaction in modern times [10].

Marketing activities at tourist destinations level are designed to support the basic elements of the destination in order to attract potential tourists to visit a destination, and to use the services within the destination, ensuring that the expectations of visitors / tourists are met within the destination itself. In this framework, the strategic nature of decision-making on defining the marketing mix requires its constant adaptation to changing market conditions. Turbulence of changes in the environment and inability to precisely anticipate these changes significantly impede the creation of long-term meaningful combination of marketing mix instruments. This is also the reason that approach to defining the marketing mix must be dynamic, and it should serve as the basis for a permanent adjustment to internal and external changes. One of the forms of this adjustment is the use of social media, especially by destination marketing organisations. This is especially important for Serbia as a tourist destination, due to the basic characteristics of its tourism development as well as to results of this development.

\section{SOCIAL MEDIA AND TOURISM}

Social media engenders a number of different terms, many of which are used interchangeably, leading authors to concur that the terminology continues to elude sure definition. Terms include social media, user-generated content (UGC), consumer generated media (CGM), online social networks (OSN), social networking sites (SNS), Web 2.0 and Travel 2.0. [11, 12, 13,14]. Social media generally refers to web applications that allow for the user to post and share content. They are providing four main benefits: communication, collaboration, community, and collective intelligence opportunities [6]

Prior to Web 2.0, the Internet functioned solely in one direction - a 'read-only' format [15] Web 2.0 propelled by user-generated content through social media and social network sites. Social media refers to activities, practices, and behaviours among communities of people who gather online to share information, knowledge, and opinions using conversational media. Conversational media are webbased applications that make it possible to create and easily transmit content in the form of words, pictures, videos, and audios [16]. The advent of social media and the shift from Web 1.0 to Web 2.0 also marks the shift from wordof mouth to world-of-mouth [17]. The focus of Web 1.0 was on delivering products. Web 2.0 had permitted a shift to deliver services that can be used and combined with other services in new ways and presented the interactivity with end users in new ways, enabling users to drive what is important or of the most value [18].

Social media or social networking sites generally refer to web applications that allow for the user to post and share content. Common social media applications include Facebook, Twitter, You Tube, Google+, Pinterest, Instagram Foursquare, Flickr. Some authors have attempted to classify social media into six types: social networking sites, blogs, virtual social worlds, collaborative projects, content communities, and virtual game worlds [13].

Social media provide a great array of online venues for destination management organizations (DMOs) to distribute information and communicate with others. Some of the most important activities in which DMOs can engage on the social networks are [19]:

- Building and maintaining communities of interests: For DMOs the goal is to build communities that have an interest in their specific destination.

- Collecting user-generated content: People post their blogs, comments, videos and photographs of trips to destinations

- Displaying photography and video: Some of the social media channels are designed specifically for displaying visual materials, e.g. YouTube and Vimeo (for videos) and Instagram, Pinterest or Flickr (for photographs).

- Distributing topical news stories: Social networks are great place for DMOs to 'push out' news stories about their destinations, through distribution to communities of people that have indicated an interest in the destination.

- Emphasizing current events and campaigns: The social networks are very timely and people are constantly checking them. Placing upcoming events and new promotional programs here gives a freshness to the information.

- Encouraging word-of-mouth recommendations: The positive recommendations of past visitors may influence others to go to the destinations.

- Getting feedback: Some DMOs conduct pools and place research surveys on social networks.

With the change in the nature of communication and notions of community there has been a change in how travellers gather information and make their travel decisions. Generally, travellers place a high degree of trust in their social media networks - information is gathered and synthesized from other travellers. Knowledge of the travel destination is acquired through social interaction, 
in addition to traditional market-generated materials and web sites - including DMOs [20].

It is very important to stress that DMOs as well as DMaOs will face serious challenges in the near future. The first challenge was adapting to technological change. In the current economic climate of public austerity NTOs and more regionally and locally focused DMOs and tourism boards, are losing elements of their funding, offices and the ability to market as widely as they did previously. Many DMOs turn to social media as a relative low-cost and global reach marketing tool. Marketing via social media seems to be what is most relevant to the way in which tourism is utilising social media. A clear understanding of why and how social media function is vital to tourism destination marketing. One sizeable gap in the existing literature is research examining the use of social media by tourism DMOs. Little research has been conducted to study how tourism entities are evolving with the Internet and using social media to market destinations and engage with potential consumers. Consequently, there is a lack of understanding of social media platforms and usage related to tourism [4].

Marketing activities at tourist destinations level are designed to support the basic elements of the destination in order to attract potential tourists to visit a destination, and to use the services within the destination, ensuring that the expectations of visitors / tourists are met within the destination itself. In this framework, the strategic nature of decision-making on defining the marketing mix requires its constant adaptation to changing market conditions. Turbulence of changes in the environment and inability to precisely anticipate these changes significantly impede the creation of long-term meaningful combination of marketing mix instruments. This is also the reason that approach to defining the marketing mix must be dynamic, and it should serve as the basis for a permanent adjustment to internal and external changes. One of the forms of this adjustment is the use of social media, especially by destination marketing organisations. This is especially important for Serbia as a tourist destination, due to the basic characteristics of its tourism development as well as to results of this development.

\section{USE OF THE SOCIAL MEDIA BY SERBIAN DESTINATION MARKETING ORGANISATIONS}

Tourism is one of the untapped development opportunities in Serbia. Out of all production factors, which are the basis for achieving competitive advantage, a positive effect is provided only by natural resources, as well as historic and cultural resources. All other production factors can be considered, in the present conditions, either as insufficiently stimulating or as limiting for the comparative advantage that is a prerequisite for achieving competitiveness of Serbia as a tourist destination. Due to the insufficient supply of human resources, capital, and inadequate levels of infrastructure and superstructure, it was impossible to use resources in the efficient and effective way in order to create competitive advantages of tourism in Serbia on the international market. The result is the current position of Serbia on the international tourism market, the level of tourism development, particularly evident in the scope and structure of tourist traffic and tourist consumption. [21]

One of the most comprehensive approaches to the analysis of the competitiveness of tourist destinations is the Travel and Tourism Competitiveness Index of countries as tourist destinations by the World Economic Forum (TTCI). According to this Index in 2013, Serbia was on the 89th position among 140 countries, and on the 40th position in Europe among 42 countries [22]. Having in mind the results of analysis, Serbia lags largely behind its competitors and by all indicators it is behind all the countries that make up the competitive set. [23]

The Travel \& Tourism Competitiveness Index (TTCI) consists of three sub-indices: Travel and Tourism Regulatory Framework, Business Environment and Infrastructure, and Travel and Tourism Human, Cultural, and Natural Resources. One part of the sub-index called Business Environment and Infrastructure is also ICT infrastructure. In 2013, ICT infrastructure, as a part of TTCI for Serbia, is ranked as 49 th out of 140 countries with score 3,6 out of 7. In the frame of this sub-index are following ranks for Serbia [22]: ICT use for B-to-B transactions - 117, ICT use for B-to-C transaction - 122, Individual usage of the Internet - 67, Fixed telephone lines - 30, Broadband Internet subscribers - 51, Mobile telephone subscriptions - 37 and Mobile broadband subscriptions - 37. There are serious obstacles regarding use of ICT, especially for B-B and B-C transactions.

Organisation of marketing activities at destination level in Serbia is defined by Serbian Law on Tourism. A special part of the Law on Tourism of the Republic of Serbia is dedicated to the" tourism organisations for promoting tourism". In this framework, it is stipulated that tourism promotion is conducted by: Tourism organisation of Serbia, tourism organisation of the autonomous province and tourism organisations of local governments (cities and municipalities). In the addition to this, the promotion of tourism can be performed also by regional tourism organisations, established by two or more units of local government.

According to the Law on Tourism of the Republic of Serbia [24], Tourism Organisation of Serbia is established for performing tourism promotional activities, coordination of activities of tourism organisations, businesses and other stakeholders in tourism in the Republic of Serbia. Its main tasks are to promote tourism of the Republic of Serbia, to coordinate the activities of tourism organisations, businesses and other stakeholders in the tourism industry, which act directly or indirectly in tourism promotion, to organise tourism market researches for the purpose of tourism promotion of the Republic of Serbia, as well as to perform international cooperation. As an important way of conducting promotional activities, the providing of information and promotional material to promote tourist values (printed publications, audio and video promotional materials, web sites, souvenirs, etc.) is emphasised. Similar scope is defined by the Law on Tourism for the provincial tourism organisation as well as for the tourism organisations of cities and municipalities. 
Tourist Organization of Serbia operates as a classical destination marketing organisation, with the prime task to promote tourism on the domestic and international markets. In addition, to a certain extent, although outside of the definition of tourism organisations in the text of the Law, its participation in the development of the tourism product could be mentioned. Basically, it applies also to tourism organizations at lower levels.

Law on Tourism of the Republic of Serbia does not provide the possibility of establishing destination management organisations. The scope of tourism organisations is restricted almost entirely to the promotion as a marketing tool or, better to say, to an external destination marketing, while performing of activities related to the internal development of a destination is in another bodies' jurisdiction, primarily governmental authorities.

The ability to establish DMO exists based on the broader interpretation of one of the articles of the Law that allows the establishment of organisations for operational, marketing and promotional activities, which would be comprised of representatives of one or more municipalities including also local tourism organisations, representatives of the private sector and other key stakeholders in the form of public-private partnership.

There is no doubt that in the future, in line with international trends and experiences, the legal basis for the establishment of destination management organisations in Serbia will be created. The diversity of the level of tourism development within Serbia and the need for more intensive state involvement in incentivising the tourism development, especially in order to equalise regional differences, are additional factors that point out to creation of the legal basis for a different approach to establishing the organisations for managing the development of tourist destinations. It is evident that there is a need for establishing of DMOs on the level of developed tourist destinations in Serbia (Belgrade, Novi Sad, Zlatibor, Kopaonik, Vrnjačka Banja, etc.), as outlined in respective strategies and master plans that were developed for priority tourist destinations of Serbia [25].

Using of social media as marketing tool by tourism organisations at all levels in Serbia is still in the introductory phase. On one hand, this may be the result of the traditional approach to tourism organisations' operations based on their para-governmental status, and on the other hand, of the lack of necessary preconditions (human resources, financial resources). As in other countries, in Serbia there is a lack of understanding of the importance of social media platforms and their use in the tourism as well as a lack of the research on the use of social media as a part of marketing activities.

One of the main specifics of using marketing in tourism is derived from the existence of multiple levels of marketing activities carriers. As the main subjects, there are tourism companies (micro level) and tourist destinations (macro level - state, region, tourist resort). This characteristic in the using of the marketing especially refers to the organising of marketing communication activities.

The distribution of responsibilities and the specific organisation of tourism at micro and macro levels are an important prerequisite for the distribution of responsibilities in the management of tourism development. Activities at the macro level, which can be done through appropriate bodies and institutions, form a consistent framework of tourist destination marketing. Bearing in mind that the majority of tourists are influenced, when deciding on booking and buying, by the features of a tourist destination, it is clear that marketing activities, especially marketing communications, organised at the macro level, have significant impact on the activities of tourism companies. Having this in mind, in order to illustrate the basic conditions for the use of social media as a part of marketing activities, we focused on presence of Serbian tourism organisations at social media. This presence does not mean also the regular use of social media in marketing activities but only testifies that there is the recognition of the importance of the presence at social media and of the communication with potential tourists. Data on the presence were obtained by direct inspection of the presence of tourist organisations in specific social networks in the period of February 17-22, 2014. Obtained results were compared and, in some cases, supplemented by data obtained from the NTOS.

Table 1. Presence of tourism organisations in Serbia at the social media (excluding the territory of AP Kosovo and Metohija)

\begin{tabular}{|c|c|c|c|c|c|l|}
\hline \multirow{2}{*}{ TO } & TO & \multicolumn{5}{|c|}{ Social Media } \\
\cline { 2 - 7 } & $\begin{array}{c}\text { Overall } \\
\text { number }\end{array}$ & $\begin{array}{c}\text { Face- } \\
\text { book }\end{array}$ & $\begin{array}{c}\text { Twit- } \\
\text { ter }\end{array}$ & $\begin{array}{c}\text { You- } \\
\text { Tube }\end{array}$ & $\begin{array}{c}\text { Goog- } \\
\text { le+ }\end{array}$ & $\begin{array}{l}\text { Oth- } \\
\text { er }\end{array}$ \\
\hline NTOS & 1 & 1 & 1 & 1 & 1 & 1 \\
\hline TOV & 1 & 1 & - & 1 & - & - \\
\hline RTO & 1 & 1 & 1 & - & - & - \\
\hline CTO & 23 & 22 & 5 & 10 & 3 & 5 \\
\hline LTO & 122 & 63 & 18 & 16 & 16 & 9 \\
\hline
\end{tabular}

NTOS - National Tourism Organization of Serbia, TOV - Tourist Organisation of Vojvodina, RTO - Regional Tourist Organisation Western Serbia, CTO - City Tourism Orgtanisation, LTO - Local (Municipal) Tourism Organization

The research results indicate that the most common social network used in the activities of tourism organisations in Serbia is Facebook. It contains own pages of national, provincial and regional TO Western Serbia and $95.7 \%$ of the city (all except Pančevo) and $51.6 \%$ of the municipal TOs. Twitter witnesses the presence of the NTOS and regional tourist organisation, and in addition $21.7 \%$ of the city and $14.8 \%$ of the municipal TOs. At YouTube there are national and provincial TOs, and $43.5 \%$ of city and $13.1 \%$ of the municipal TOs. At Google+ there is the NTOS and $13 \%$ of city and $13.1 \%$ of the municipal TOs. At all other social media (Instagram, Pinterest, Foursquare, Vimeo, etc.) there are $10.1 \%$ TOs at all levels.

These results testify about relatively good presence of TO Serbia on social networks, especially on Facebook. A closer look at the scope and structure of activities on 
these social media led to the conclusion that they were, at all levels, used occasionally, unselectively and without clearly defined strategy. In some cases, at the local level, there were pages and accounts that had not been updated for over a year and where in the long term there had not been any form of communication with potential customers. Also, in the most cases, there were only pages in the Serbian language.

In any case, above initial study did not allow the adoption of the very important conclusions about the use of social networks in marketing activities of tourism organisations in Serbia. Anyway, it can serve as a starting point for future research, particularly for content analysis of official accounts of national, provincial, regional, city and selected municipal TOs, especially on Facebook and Twitter. As a good example in this respect, there is the research referring to the official Facebook pages and Twitter accounts of ten world's leading tourist destinations. There is no doubt that this research results should be taken into consideration, and they indicate that the DMOs are still in the introductory stage of understanding and verifying of the possibilities for using social media in order to promote their tourist destinations. In particular, it emphasises the importance of the experience gained by Visit Britain and Tourism Queensland, while the experiences of other destinations are determined as largely rudimentary. [4]

For tourism organisations in Serbia, three key research results are especially important: Firstly, the majority of the examined DMOs are not currently utilising social media to their full effectiveness when it comes to the ability to interact and engage with consumers. Secondly, social media is still not widely recognised and/or respected as a vital tool in marketing strategies, and thus is frequently underfunded and/or neglected. Lastly, DMOs could benefit from becoming even more innovative and creative when it comes to their social media strategies, in order to fully differentiate these efforts from traditional marketing methods [4]

An important prerequisite for the use of social media as a marketing tool by Serbian tourism organisations is the development and adoption of Social media tourism marketing strategy. One example of the adoption and implementation of such a strategy is Slovenia [26].

While the time is running fast to year 2015 as the final year of validity of the current Tourism development strategy of Serbia, with so-called Review of the current strategy proved to be unsuccessful and unenforceable, and since the Strategy of promotional activities of Serbia as tourist destination has not been adopted yet, the most efficient and fastest way to modernise Serbian tourism marketing approach could be the implementation of appropriate Social media tourism marketing strategy. This paper can be also seen as a contribution to creating awareness of the need for such a strategy, in which the basis should be striving for integration of digital and traditional media as a key goal for successful destination marketing.

\section{REFERENCES}

[1] Hoffman, D. The revolution will not be televised: Introduction to the special issue on Marketing Science and the Internet. Marketing Science, 19 (10), 2000, pp. 1-3.
[2] Barwise, P., Elberse, A. and Hammond, K., Marketing and the Internet. In B. Weitz \& R. Wensley (Eds.). Handbook of Marketing (pp. 527-557), Thousand Oaks, CA: Sage Publications Inc. 2006.

[3] Buhalis, D., Jun, S.H, E., Tourism, Contemporary Tourism Reviews, Goodfellow Publishers Limited, 2011, Woodeaton, Oxford,

[4] Hays, S., Page, S.J., Buhalis, D., Social media as a destination marketing tool: its use by national tourism organisations, Current Issues in Tourism, 16 (3), 2013, pp. 211-239, DOI: $10.1080 / 13683500.2012 .662215$

[5] Boyd, D., \& Ellison, N. (2008). Social network sites: Definition, history, and scholarship. Journal of Computer-Mediated Communication, 13, 2008, pp. 210-230.

[6] Jucan, M., Jucan, C., Rotariu, I., “The Social Destination": How Social Media Influences the Organisational Structure and Leadership of DMOs, World Academy of Science, Engineering and Technology 78, 2013, pp. 1426-1432.

[7] Popesku, J., Marketing u turizmu, Univerzitet Singidunum, Beograd, 2013.

[8] Middleton, V.T.C, Fyall, A., Moran, M., Marketing in Travel and Tourism, Butterworth-Heinemann, Oxford, 2009.

[9] Boyd, D., Ellison, N., Social network sites: Definition, history, and scholarship. Journal of Computer-Mediated Communication, 13, 2008, pp. 210-230.

[10] Lange-Faria W., Elliot, S., Understanding the role of social media in destination marketing, Tourismos, 7 (1), 2012, pp. 193-211.

[11] Cox, C., Burgess, S., Sellitto, C. \& Buultjens, J., The role of user-generated content in tourists' travel planning behaviour. Journal of Hospitality Marketing \& Management, 18 (8), 2009, pp. 743-764.

[12] Dippelreiter, B., et al., Online tourism communities on the path to Web 2.0: An evaluation. Information Technology \& Tourism, 10 (4), 2008, pp. 329-353.

[13] Kaplan, A.M. \& Haenlein, M., Users of the world, unite! The challenges and opportunities of Social Media. Business Horizons, 53 (1), 2010, pp. 59-68.

[14] Xiang, Z. \& Gretzel, U., Role of social media in online travel information search. Tourism Management, 31 (2), 2010, pp. 179-188.

[15] Borges, B., Marketing 2.0: Bridging the gap between seller and buyer through social media marketing. Wheatmark, Tucson, 2009.

[16] Brake, D., \& Safko, L., The social media bible. John Wiley and Sons, Inc., Hoboken, 2009.

[17] Qualman, E., Socialnomics: How social media transforms the way we live and do business, John Wiley and Sons.Hoboken, 2009.

[18] Bernal, J., Web 2.0 and Social Networking for the Enterprise, IBM Press, 2010.

[19] Morrison, A., Marketing and Managing Tourism Destinations, Routledge, Oxon, 2013.

[20] Buhalis, D. \& Law, R., Progress in information technology and tourism management: 20 years on and 10 years after the Internet - the state of eTourism research. Tourism Management, 29.(4), 2008, pp.609-623.

[21] Popesku, J., Menadžment turističke destinacije, Univerzitet Singidunum, 2013.

[22] Blanke, J., Chiesa, T., The Travel and Tourism Competitiveness Report 2013, World Economic Forum, Geneva, 2013. 
[23] Popesku, J., Pavlović, D., Competitiveness of Serbia as a Tourist Destination - Analysis of Selected Key Indicators, Marketing, 44 (3), 2013, pp. 199-210.

[24] www.turizam.privreda.gov.rs/images/stories/materijal/ pravilnici\%20lat/ZAKON\%20O\%20TURIZMU.pdf

[25] Popesku, J., Destination management organisations as a form of managing development of tourist destinations, Proceedings of the Scientific Meeting 'Synergy 2009', Synergy University, Bijeljina, 2009, http://www.singipedia. com/attachment.php?attachmentid=690\&d=1275918395

[26] Kapitanovič-Pavlovčič, T., A Practical Approach to Social Media: STB Experience, http://www.slideshare.net/mpsarros/slovenian-tourist-board-social-media-marketing. 